Helgoländer wiss. Meeresunters. 30, 527-545 (1977)

\title{
A seasonal carbon budget for a laminarian population in a Scottish sea-loch
}

\author{
C. S. Johnston ${ }^{1}$, R. G. Jones ${ }^{2} \&$ R. D. Hunt ${ }^{1}$ \\ ${ }^{1}$ Department of Biological Sciences, Heriot-Watt University; \\ Edinburgh, Scotland, U.K., \\ and \\ 2 North West Water Autbority, Rivers Division; \\ Great Sankey, Warrington, U.K.
}

\begin{abstract}
Employing in situ SCUBA methods, a seasonal carbon budget has been established for a Laminaria saccharina population in a Scottish sea-loch. Concurrent studies of photosynthesis, secretion rates, reserve fluctuations and frond growth were undertaken. Net annual production is in excess of $120 \mathrm{~g} \mathrm{C} \mathrm{m}^{-2} \mathrm{yr}^{-1}$. Over $13 \%$ of gross carbon input is released as extracellular secretions (over $30 \%$ in autumn) and $40-50 \%$ is lost by distal decay, entering detrital food chains. The large concentrations of laminarin, synthesised in summer months, are nearly all lost in autumn-winter distal tissue loss and therefore not available for early spring growth.
\end{abstract}

\section{INTRODUCTION}

Benthic seaweeds, whose standing crops may exceed those of phytoplankton by a hundred-fold in inshore waters (Blinks, 1955) have been largely ignored in energetics studies. Estimates of production based on short-term photosynthesis studies have suggested very high rates of production (Kanwisher, 1966) but attempts to relate such figures to field conditions have usually met with considerable controversy. However as early as 1948 , studies by Parke provided convincing evidence for high growth rates in sub-tidal kelps. Recently, Mann (1972) has suggested very high production rates for seaweeds in Canadian waters $\left(1750 \mathrm{~g} \mathrm{~m}^{-2}\right.$ year $\left.{ }^{-1}\right)$, using direct SCUBA-based studies of lamina growth. At the same time as the earlier growth studies (Parke, 1948) detailed investigations were being undertaken of seasonal fluctuations in seaweed constituents notably the carbohydrates laminarin and mannitol and general relationships to growth conditions suggested (Black, 1950).

Laboratory investigations have also resulted in a controversy regarding the possible secretion of large quantities of extracellular products from seaweeds. Several workers, notably Khailov \& Burlakova (1969) and Sieburth (1969) have suggested that up to $40 \%$ of gross photosynthetically-fixed carbon may be released as extracellular secretions. However, Brylinsky (1971), followed by other workers including Moebus \& Johnson (1974) using ${ }^{14} \mathrm{C}$-labelling methods, has suggested that only very low levels of assimilate are secreted (lower than $4 \%$ ). 
To date, a complete annual budget for carbon balance within a seaweed has not yet been achieved. It would seem that attempts to relate photosynthetic and secretion rates to observed field performance have been based more on extrapolation with innumerable assumptions (or hopes!) than in planned experimentation.

This study outlines an attempt to produce a preliminary carbon budget by undertaking concurrent studies of photosynthesis, chemical changes, growth and extracellular secretions in the fronds of a shelter-water population of Laminaria saccharina, employing SCUBA-based in-situ methods, in Loch Creran, Scotland.

\section{LOCATION OF INVESTIGATION}

The field estimates of productivity were undertaken at a site approaching the head of Loch Creran, near Oban, Strathclyde (Fig. 1), just north of the marine research laboratory of the Scottish Marine Biological Association (SMBA). The macroalgae

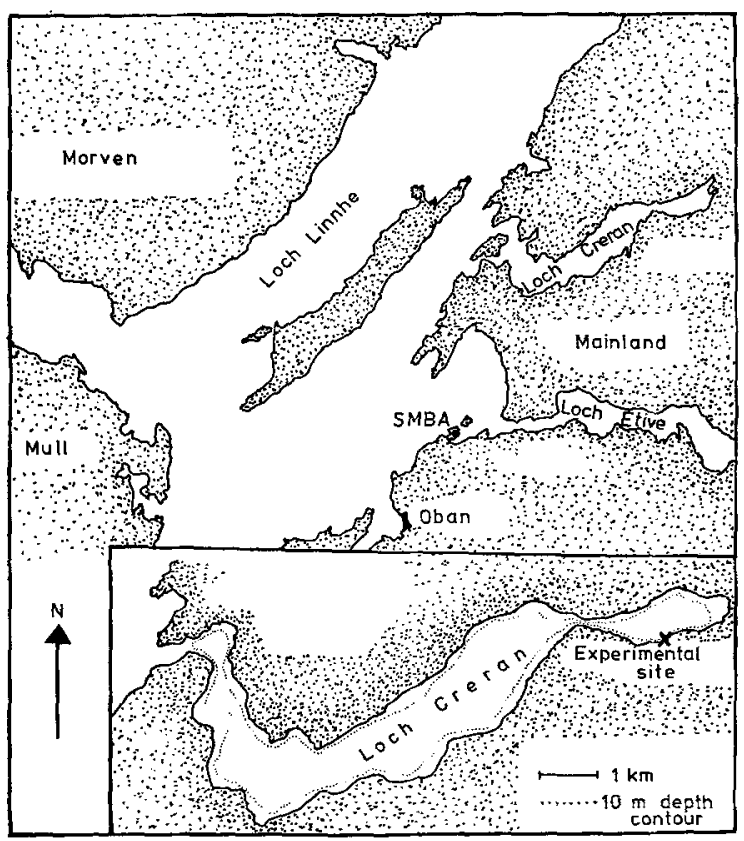

Fig. 1: Location of field studies in Loch Creran

present, reflected the sheltered nature of the location. The predominant brown algae in the littoral zone were Ascophyllum nodosum (L.) Le Jol interspersed with Fucus vesiculosus L. Near low water a small bank of Fucus serratus $\mathrm{L}$. is found. The sub-littoral substratum consisted of a short bank of boulders levelling to a more gentle slope of sand/silt. At $12 \mathrm{~m}$ the sand-silt gives way to a rocky escarpment. The only laminarian species present at the site was Laminaria saccharina which was found attached to the 
boulder bank and to small stones or shells (eg. mussels) scattered on the bottom. The depth limit of this laminarian zone was $10 \mathrm{~m}$. Other laminarian species were recorded in the outer reaches of the loch.

\section{METHODS}

Photosynthesis was determined by methods based on those described by Johnston \& Cook (1968), Johnston (1969), and Johnston et al. (1977), employing both ${ }^{14} \mathrm{C}$ incorporation (Steeman-Nielsen, 1952) and $\mathrm{O}_{2}$ exchange measurements using the polarographic electrode (Kanwisher, 1959). All tissue and water handling and incubation were carried out in situ in the subtidal laminarian community (at $5 \mathrm{~m}$ ) using SCUBA diving methods. In the ${ }^{14} \mathrm{C}$ incorporation studies, tissue was wet combusted to carbon dioxide by a method based on that of Watson \& Williams (1970). Carbon dioxide was then trapped in 3:1 (v/v) 2-methoxyethanol : ethanolamine in a modified liquid scintillation vial. After $\mathrm{CO}_{2}$-trapping, a xylene-based scintillant was added to the vial, allowed to stand in the dark for one hour (to reduce chemoluminescence) and counted in a Packard "Tricarb" Liquid Scintillation Spectrometer employing channelsratio and external standard quench correction procedures. Total carbonate concentration in the seawater was determined by the method described by Strickland \& Parsons (1968).

Surface irradiance in the visible wavebands was continuously measured at the SMBA Laboratory, at Oban, using a Kipp and Zonen solarimeter. Underwater irradiance was measured in the range $400-700 \mathrm{~nm}$ using a Lambda Instruments L1-185 quantum sensor, backed by equivalent surface measurements at the experimental site.

Mannitol determination was based on the periodate oxidation of sugar alcohols as described by Lewis \& Smith (1967), following the removal of protein and "tannins" which would otherwise interfere with the estimation.

Although the data presented in this production budget finally included laminarin figures from Black (1950), comparable figures were obtained with the Loch Creran plants using a new method developed in this department, which will be fully reported in a subsequent paper giving more details of frond physiology. In the assay procedure, laminarin hydrolysis was made specific for laminarin by using a purified $\beta$ 1:3-glucanase enzyme preparation.

The enzyme was prepared from "Gluvanase-GV" by ammonium sulphate precipitation and chromatography on DEAE cellulose according to the method described by Wilson (1972). Carbon analyses were carried out employing a Perkin-Elmer Elemental Analyser.

\section{RESULTS}

Net-photosynthesis determinations

Previous studies (Johnston et al., in press) have highlighted many of the problems encountered in attempting to relate the results of short-term, "closed incubation" studies using tissue segments to true field conditions. However, preliminary studies 
with these plants from extremely sheltered conditions suggest that any errors are likely to be minimal.

A comparison of photosynthetic rates determined by different methods shows a general trend for gross photosynthesis by the oxygen method to be higher than photosynthesis determined by the ${ }^{14} \mathrm{C}$-technique (Figs. $2 \& 3$ ). This has been observed in other macroalgae (Johnston \& Cook, 1968) and attributed to a refixation of respiratory ${ }^{14} \mathrm{CO}_{2}$ and the difficulty of assessing the P. Q. Exceptions to this general trend are the meristematic and $30 \mathrm{~cm}$ regions in March where the ${ }^{14} \mathrm{C}$-based rates are highest, perhaps implying non-photosynthetic, light-stimulated $\mathrm{CO}_{2}$ uptake. During these ${ }^{14} \mathrm{C}$-estimates of photosynthesis negligible quantities of ${ }^{14} \mathrm{C}$-extracellular materials were encountered in the seawater employed (less than $1 \%$ of total incorporated ${ }^{14} \mathrm{C}$ ), and were not included in subsequent calculations of photosynthesis.

Such estimates of photosynthesis were made at regular intervals throughout the year and the values obtained were plotted against in situ irradiance at the time of the experiments, and P v I (photosynthesis versus irradiance) curves were plotted on both an area and weight basis (Figs. $2 \& 3$ ). When photosynthesis was plotted on an area
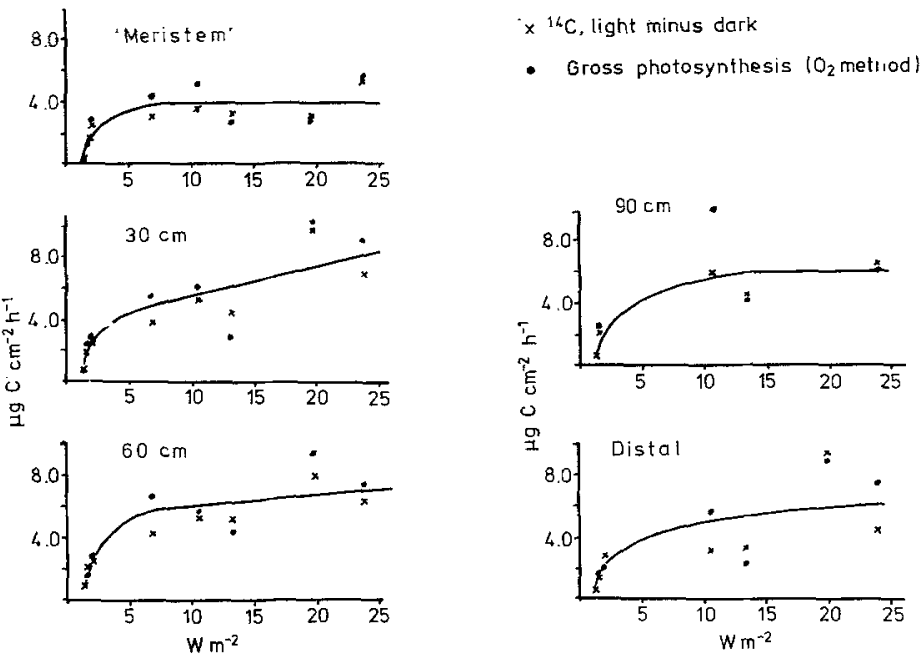

Fig. 2: Relationship between photosynthetic rates of frond regions of Laminaria saccharina and in situ visible irradiance (area basis)

basis against irradiance, curves approximating to a hyperbolic relationship were obtained. When weight based plots were made the meristem, $90 \mathrm{~cm}$ region and decaying tissue exhibited hyperbolic relationships whereas partially linear plots were obtained for the 30 and $60 \mathrm{~cm}$ regions presumably resulting from the effects of the seasonal variations in tissue density in these regions. All subsequent calculations were based on area-based photosynthetic data (Fig. 2).

The mature tissue of the 30,60 and $90 \mathrm{~cm}$ regions consistently showed higher rates of photosynthesis compared to the meristem regions. This distribution was also found 
in the uptake of ${ }^{14} \mathrm{C}$-bicarbonate by whole fronds. Obviously considerable errors could occur if frond production figures were obtained from studies of only one frond region.
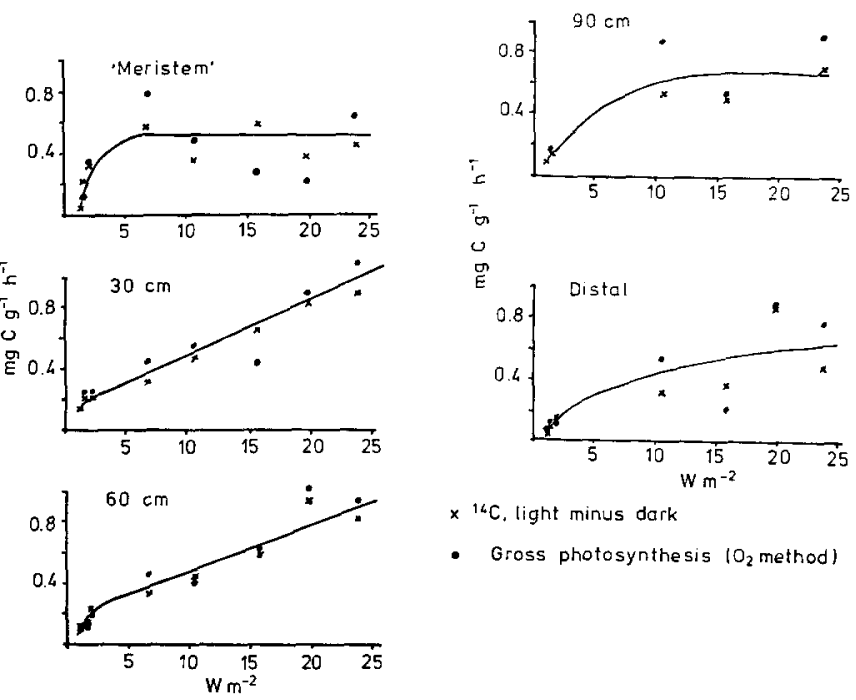

$\times{ }^{14} \mathrm{C}$. light minus dark

- Gross photosynthesis $\left(\mathrm{O}_{2}\right.$ method)

Fig. 3: Relationship between photosynthetic rates of frond regions of Laminaria saccharina and in situ visible irradiance (dry weight basis)

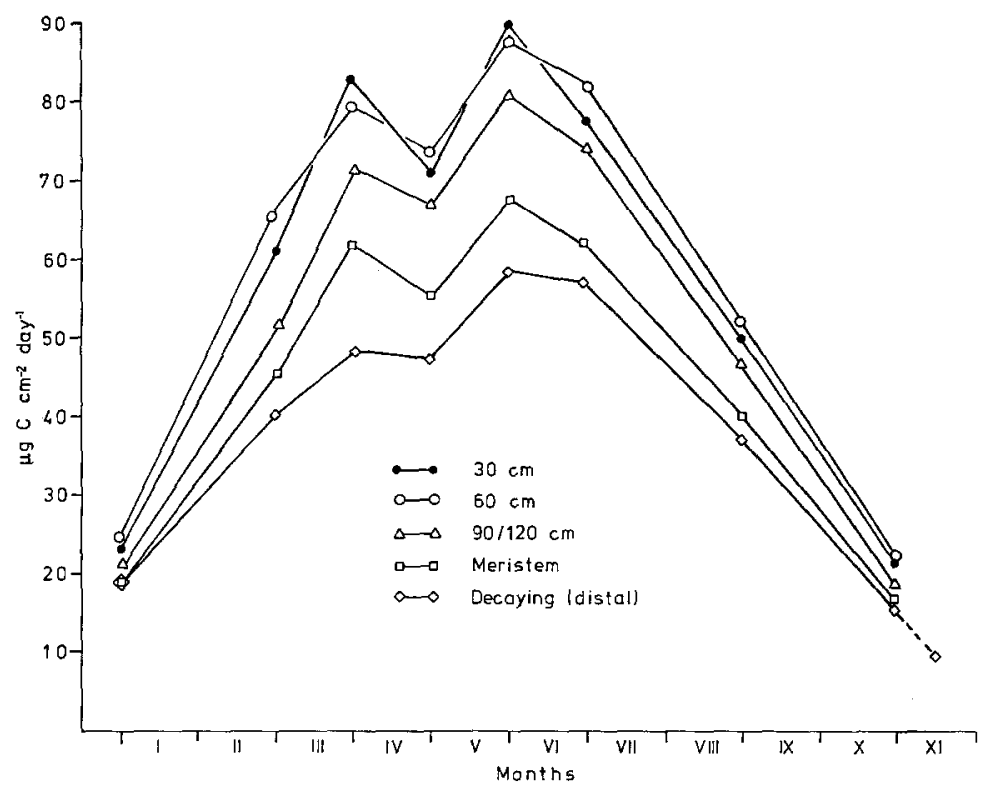

Fig. 4: Daily photosynthetic fixation of carbon by frond regions 
From field P v I studies and available laboratory data, saturating irradiance (of P.A.R.) of $24 \mathrm{WM}^{-2}$ was established for mature tissue photosynthesis. Thus to calculate photosynthetically "useable" light, this figure was assumed and all hourly irradiance values greater than this value were "rounded down" to 24 prior to computation of the monthly mean irradiance for the appropriate hour of the day (Table 1).

Table 1

Hourly photosynthetically useable irradiance in situ (values given as $\mathrm{W}^{-2}$ ). Values are monthly averages for the particular hours

\begin{tabular}{|crrrrrrrrr}
\hline Time & Jan & Mar & Apr & May & Jun & Jul & Sep & Nov \\
\hline 03 & & & & & 0.28 & & & \\
04 & & & & 0.76 & 2.20 & 0.84 & & \\
05 & & & 2.31 & 2.76 & 5.28 & 3.08 & 0.34 & \\
06 & & 1.43 & 6.60 & 5.84 & 9.72 & 5.76 & 1.32 & \\
07 & & 4.73 & 12.26 & 9.52 & 13.32 & 8.44 & 3.36 & \\
08 & 0.66 & 9.02 & 17.10 & 8.52 & 14.88 & 10.00 & 6.32 & 0.44 \\
09 & 2.97 & 11.88 & 19.03 & 10.70 & 14.28 & 11.10 & 8.96 & 2.36 \\
10 & 5.00 & 12.82 & 19.20 & 11.40 & 14.72 & 13.28 & 10.32 & 4.55 \\
11 & 5.55 & 16.77 & 19.80 & 14.16 & 16.04 & 13.32 & 11.12 & 4.50 \\
12 & 5.00 & 16.66 & 19.90 & 13.32 & 15.44 & 12.36 & 11.72 & 3.52 \\
13 & 5.11 & 14.57 & 20.90 & 12.92 & 16.20 & 10.36 & 10.40 & 3.41 \\
14 & 2.64 & 14.08 & 19.90 & 11.68 & 16.20 & 9.00 & 7.60 & 2.20 \\
15 & 0.82 & 9.40 & 18.30 & 11.96 & 15.28 & 9.10 & 4.88 & 0.74 \\
16 & & 5.50 & 14.19 & 9.44 & 13.48 & 8.80 & 2.44 & \\
17 & & 1.15 & 6.40 & 5.12 & 10.40 & 7.30 & 1.72 & \\
18 & & & 2.69 & 2.32 & 6.40 & 6.16 & 0.36 & \\
19 & & & & 0.60 & 2.96 & 4.04 & & \\
20 & & & & & 0.52 & 1.32 & & \\
\hline
\end{tabular}

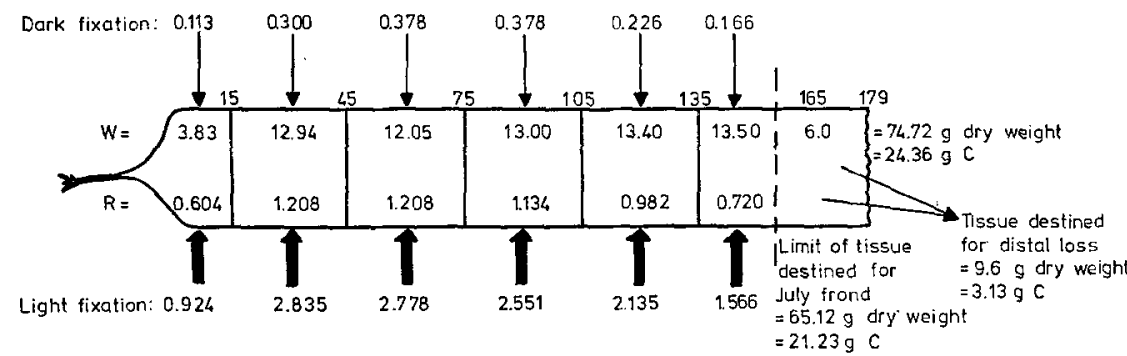

$$
\begin{array}{llll}
\text { Light } & =12.789 & \\
\text { Dark } & =1.569 & & \\
\text { Gross } & =14.350 & & \text { All units in } \mathrm{g} C / \text { month (unless otherwise stated) } \\
\text { Respiration } & =4.648 & & W=\text { dry weight }(\mathrm{g}) \\
\text { Net production } & =9.702 \mathrm{gC} & & R=\text { respiratory loss }(\mathrm{g})
\end{array}
$$

Fig. 5: Frond performance data (June)

Monthly estimates for dark fixation, gross photosynthesis, respiration and net carbon input after subtraction of respiratory demand were calculated for each frond region by applying the appropriate daily or hourly values to the areas of each frond region (monthly values for frond dimensions and weights being available from a 
population study). A detailed description of frond activity is given for 1 month as an example in Figure 5 showing how the cumulative figures quoted in Table 2 were derived.

Table 2

Annual cumulative Carbon budget for typical laminarian frond ( $\mathrm{C}$ per frond per month).

$*$ Extrapolated from relevant graph

\begin{tabular}{|cccccc|}
\hline Month & Light-fix & Dark-fix & Gross $-\mathrm{P}$ & Respiration & Net $-\mathbf{P}$ \\
\hline Jan & 2.512 & 1.538 & 4.050 & 2.553 & 1.497 \\
Feb & 5.142 & 1.205 & 6.347 & 3.062 & 3.285 \\
Mar & 8.925 & 0.968 & 9.893 & 4.335 & 5.558 \\
Apr & 12.094 & 2.189 & 14.283 & 2.749 & 11.534 \\
May & 10.492 & 2.249 & 12.741 & 3.482 & 9.259 \\
Jun & 12.789 & 1.561 & 14.350 & 4.648 & 9.702 \\
Jul & 12.884 & 1.931 & 14.815 & 4.013 & 10.802 \\
Aug & - & - & $(11.181)$ & $(4.047)$ & $7.000^{*}$ \\
Sep & 6.748 & 0.799 & 7.547 & 4.081 & 3.466 \\
Oct & - & - & $(5.605)$ & $(3.065)$ & $2.500^{*}$ \\
Nov & 1.952 & 1.710 & 3.662 & 2.048 & 1.614 \\
Dec & - & - & $(4.050)$ & $(2.553)$ & $1.497^{*}$ \\
\hline Total & & & & & 67.714 g C year $^{-1}$ \\
\hline
\end{tabular}

From Table 2 a number of key points may be noted: (1) in the winter months, particularly January, photosynthetic production falls very low, below respiratory demand, and only dark fixation maintains a net balance in the frond; (2) high carbon production exists over the period April to late July, when irradiance is at saturation for considerable parts of most days; (3) there was a small but significant drop in production in May, resulting apparently from poor water conditions in the loch; (4) these production figures exclude tissue destined for distal loss within the month of study (see Fig. 6) and relate therefore only to the internal month-month frond budget. Distal loss figures are discussed in Table 4.

\section{Frond growth and carbon flux determinations}

\section{Linear growth}

Monthly linear growth data for a population of Laminaria saccharina plants have been collected over some time at the experimental site in Loch Creran, although this budget is only concerned with studies in 1974, i. e. concurrent to the photosynthetic investigation. Employing the "punch-hole" method of Parke (1948) the growth data in Figure 6 was obtained. Although previous years have shown a more marked growth peak in February-April (often over $50 \mathrm{~cm}$ in March) the 1974 growth period extended at a fairly high rate into June. Unlike $L$. byperborea it must be noted that growth continues throughout the year, requiring: (1) suitable growth conditions all year; but (2) no massive growth demand in one season; i. e. a very different growth strategy from L. byperborea. 


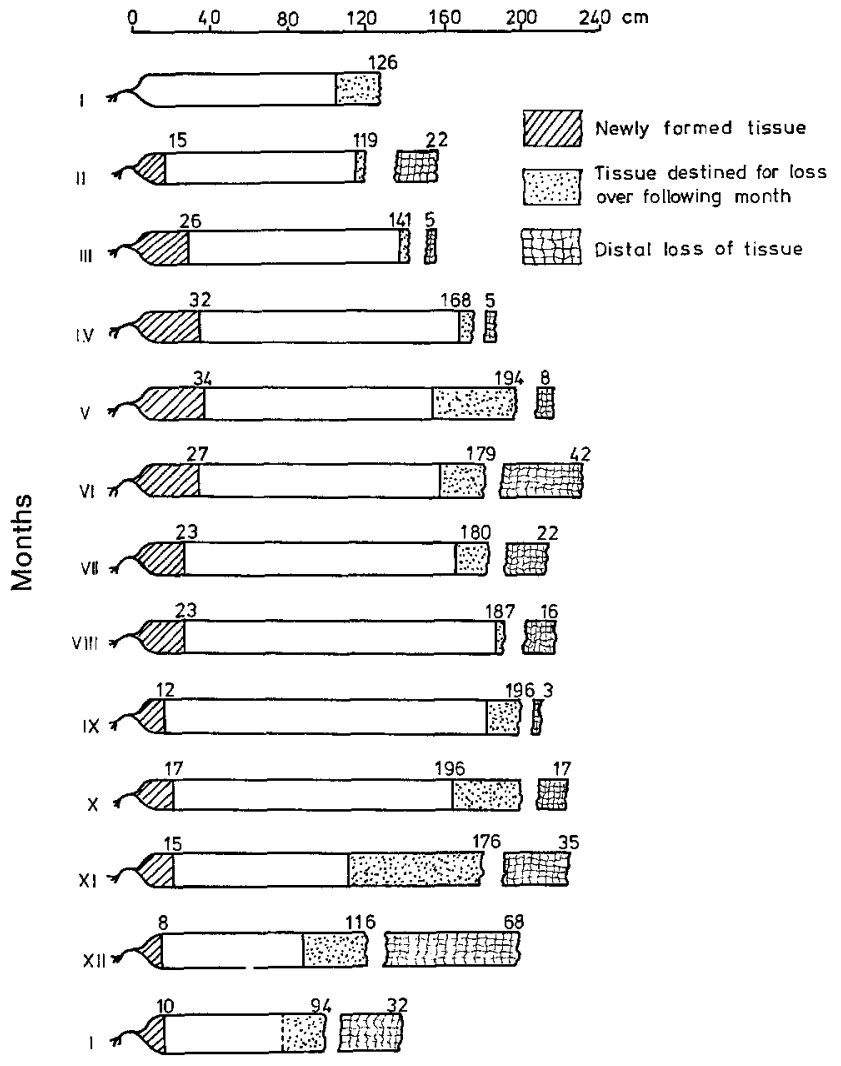

Fig. 6: Lamina dimensions and tissue growth/loss in plants employed in investigation. Numbers denote linear dimensions $(\mathrm{cm})$; all lamina widths $35 \mathrm{~cm}$

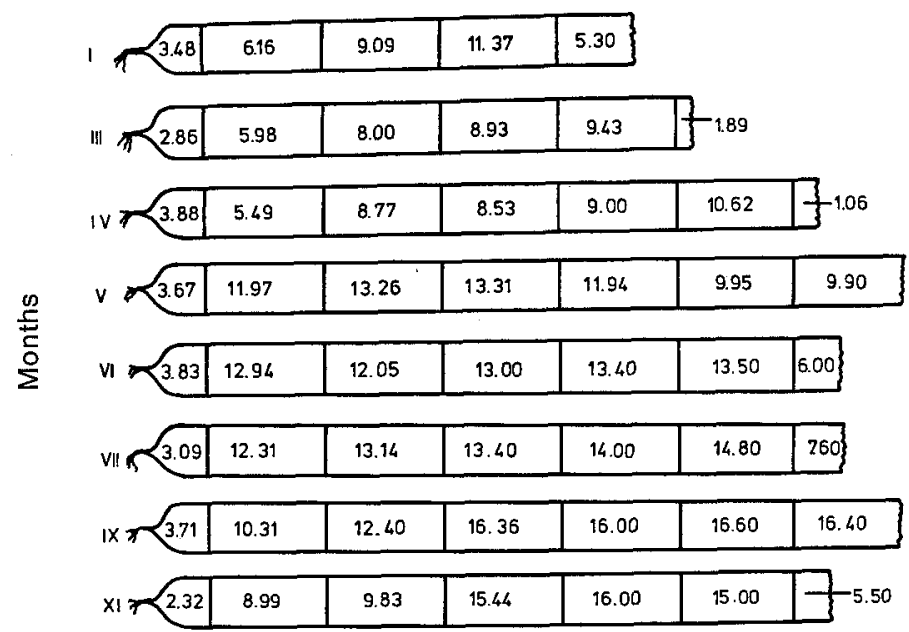

Fig. 7: Seasonal variation in dry weights (g) of frond sections 


\section{Tissue density and reserve flux}

Although there is considerable plant to plant variation in the exact seasonal pattern of dry weight (density) along the frond, Figure 7 represents a typical set of analyses. Several key points emerge: (1) tissue densities are lowest in the late winter and early spring months; (2) tissue densities are highest in the autumn (September or October); (3) a "wave" of increasing density appears to move distally over the summer months so that in the autumn the greatest tissue density is in the distal region of the frond; (4) occasionally peaks of high density occur distally in winter or even spring fronds (especially in longer fronds). These trends in dry weight reflect changes in the total level of carbon in tissue segments.

Table 3

Predicted Carbon requirement for laminarian frond growth (with growth characteristics as shown in Fig. 6)

\begin{tabular}{|cc|}
\hline Month & Growth requirement \\
\hline Jan & 0.822 \\
Feb & 1.644 \\
Mar & 2.120 \\
Apr & 4.410 \\
May & 4.271 \\
Jun & 3.772 \\
Jul & 5.446 \\
Aug & 2.691 \\
Sep & 3.909 \\
Oct & \\
Nov & Dec \\
\hline
\end{tabular}

Employing these figures for tissue carbon content it is possible to estimate approximate growth carbon requirements (Table 3) from the linear growth data in Figure 6. Table 3 shows the major growth-C demand in the period April to May.

\section{Mannitol and laminarin flux}

Two carbohydrates have been shown by several workers to undergo major seasonal flux - mannitol and laminarin (Black, 1950). Using tissue from the fronds under growth study the seasonal variation in mannitol was determined (Fig. 8).

Following a slight decrease between January and February, the mannitol concentration rises rapidly until May, shows a slight drop in June during the period of poor water conditions already discussed, and continues to rise through July then shows a very rapid fall over the late summer and autumn. Laminarian also shows a similar increase in concentration in the early summer month continuing to a peak in September-October. The rise in laminarin begins later than that of mannitol, about April, and no decrease occurs in conditions, producing temporary mannitol decreases eg. June (Black, 1950). 


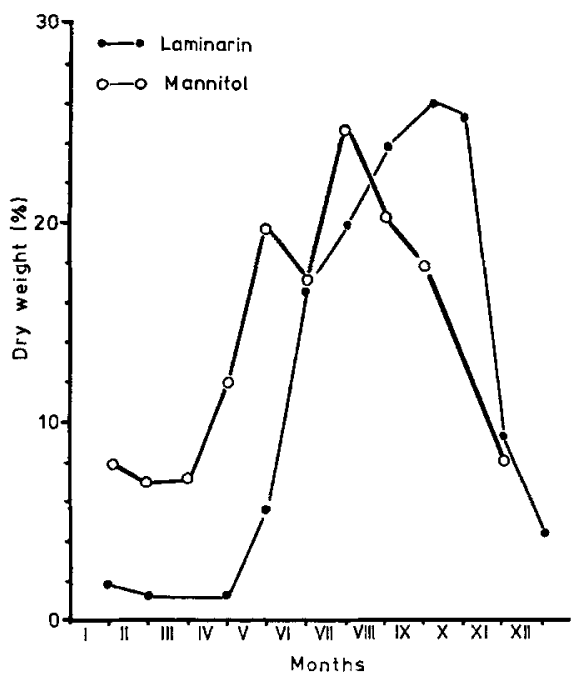

Fig. 8: Seasonal variation in laminarin and mannitol in Laminaria saccharina

\section{Summing the carbon requirements}

Employing the growth-carbon requirements quoted in Table 3 and the fluctuations in mannitol and laminarin just described (Fig. 8) an attempt was made to produce an approximate seasonal carbon requirement budget for the laminarian frond (Fig. 9). Four key observations can be made: (1) the carbon available by light and dark fixation meets winter requirements; (2) in the spring there appears to be a slight excess of carbon available which may be released from the frond as extracellular products; (3) over the summer period, late April to July, the internal frond carbon budget appears

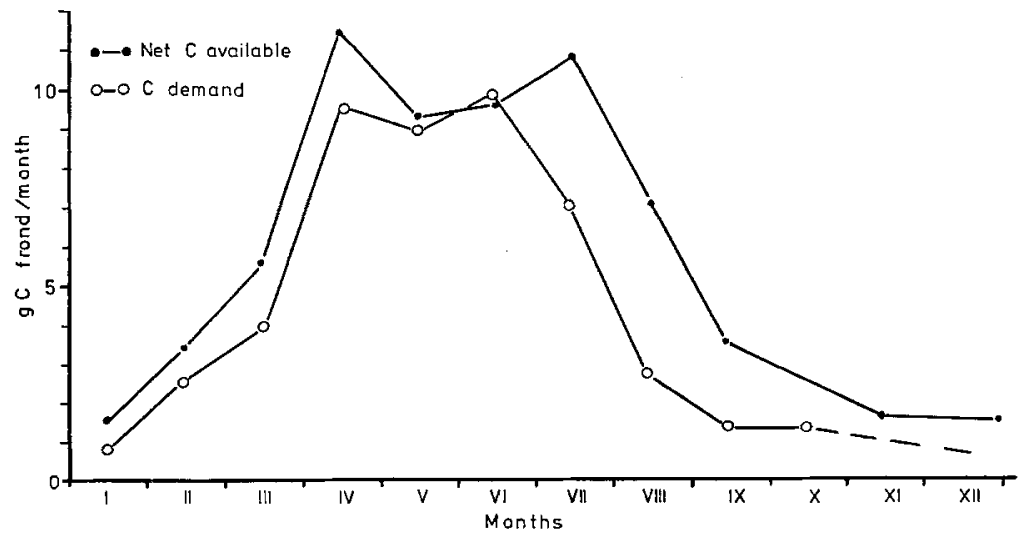

Fig. 9: Seasonal availability/demand of carbon 
to account for all the carbon available by production processes; (4) in the late summer and autumn there appears to be a considerable excess of carbon available which cannot be accounted for by internal budgeting. Several factors could explain this latter problem of excess carbon in autumn months and they will be discussed later.

\section{Distal tissue loss}

From the initial linear growth studies (Fig. 6), it is clear that frond growth follows the pattern described by Parke (1948), tissue being produced from a basal meristem and being shed from the distal end of the frond, "in effect, moving belts of tissue“ (Mann, 1972).

The pattern of distal loss is interesting with: (1) some loss all year; (2) major loss in autumn-winter, particularly November (some years, the peak loss is in October); (3) a fairly considerable loss in May-June, the period already noted for poor water conditions.

By extrapolation from Figure 6, using the dry weight data provided in Figure 7 , it is possible to quantify this pattern of distal loss. However, it must be remembered that as this tissue is shed over the month it is still undertaking a limited amount of photosynthesis which must be added to the basic tissue carbon level if an accurate estimate of distal-C loss is to be attempted ('Table 4).

Table 4

Observed annual pattern of distal tissue loss from typical laminarian frond (g C per frond per month)

\begin{tabular}{|lccc|}
\hline Month & $\begin{array}{c}\text { Measured } \\
\text { Distal tissue } \\
\text { C-content }\end{array}$ & $\begin{array}{c}\text { Distal tissue } \\
\text { production }\end{array}$ & $\begin{array}{c}\text { Total distal } \\
\text { C-release/frond }\end{array}$ \\
\hline Jan & 1.852 & 0.055 & 1.907 \\
Feb & 0.466 & 0.060 & 0.526 \\
March & 0.513 & 0.086 & 0.599 \\
Apr & 0.865 & 0.277 & 1.142 \\
May & 4.540 & 1.041 & 5.581 \\
June & 3.130 & 0.515 & 3.645 \\
July & 2.638 & 0.353 & 2.991 \\
Aug & 0.482 & 0.050 & 0.532 \\
Sept & 2.932 & 0.140 & 6.072 \\
Oct & 6.202 & 0.300 & 12.075 \\
Nov & 11.377 & 0.698 & 5.467 \\
Dec & 5.387 & 0.080 & $44.039 \mathrm{~g} \mathrm{C}$ \\
\hline Totals (annum) & 40.384 & 3.655 & \\
\hline
\end{tabular}

Clearly, although the peak period of frond productivity lies between April and July, the major contribution by the laminarian community to the inshore ecosystem is in late autumn (Oct.-Nov.).

Ecological studies of the laminarian community in the Loch Creran site suggest comparatively low leaf area indices, approaching unity, thus it is possible to present 
Table 5

Extrapolation of frond production to community production assuming leaf area index of unity (Values in $\mathrm{g} \mathrm{C} /$ month/frond)

\begin{tabular}{|lccccc|}
\hline Month & $\begin{array}{c}\text { Main } \\
\text { tissue } \\
\text { production } \\
\text { (net) }\end{array}$ & $\begin{array}{c}\text { Distal } \\
\text { tissue } \\
\text { production } \\
\text { (net) }\end{array}$ & $\begin{array}{c}\text { Total } \\
\text { production } \\
\text { (net) }\end{array}$ & $\begin{array}{c}\text { Total } \\
\text { frond } \\
\text { area }\left(\mathrm{cm}^{2}\right)\end{array}$ & $\begin{array}{c}\text { Net-P } \\
\text { (per m²) }\end{array}$ \\
\hline Jan & 1.497 & 0.055 & 1.552 & 4410 & 3.519 \\
Feb & 3.285 & 0.060 & 3.345 & 4165 & 8.031 \\
Mar & 5.558 & 0.086 & 5.644 & 4935 & 11.436 \\
Apr & 11.534 & 0.277 & 11.811 & 5880 & 20.086 \\
May & 9.259 & 1.041 & 10.300 & 6790 & 15.169 \\
June & 9.702 & 0.515 & 10.217 & 6265 & 16.308 \\
July & 10.802 & 0.353 & 11.155 & 6300 & 17.706 \\
Aug & 7.000 & 0.050 & 7.050 & 6545 & 10.771 \\
Sept & 3.466 & 0.140 & 3.606 & 6860 & 5.256 \\
Oct & 2.500 & 0.300 & 2.800 & 6860 & 4.081 \\
Nov & 1.614 & 0.698 & 2.312 & 6160 & 3.753 \\
Dec & 1.497 & 0.080 & 1.577 & 4060 & 3.884 \\
\hline$\Sigma$ & $67.714 \mathrm{~g} \mathrm{C}$ & 3.655 & 71.369 & & $120.000 \mathrm{~g} \mathrm{C} \mathrm{m}^{-2} \mathrm{yr}^{-1}$ \\
\hline
\end{tabular}

the results of this current study in the form of an assessment of laminarian contribution in inshore energetics (Table 5) as well as obtain a clearer understanding of the carbon balance within the frond itself (Fig. 10).

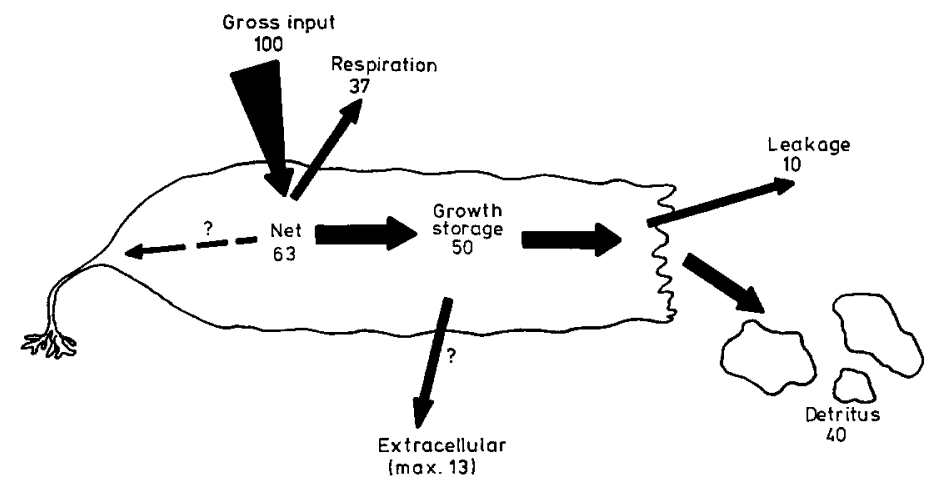

Fig. 10: Estimated fate of a gross carbon input of $100 \mathrm{~g}$ (annual)

\section{DISCUSSION}

\section{Photosynthetic and respiratory rates}

The decision to carry out concurrent, in situ, investigations of photosynthetic production, fluctuations in tissue composition and frond growth rates, reduces many of the problems in attempting to inter-relate laboratory and in-situ field measurements, 
particularly such problems as simulating true field light regimes in the laboratory and assessing the effects of incubation conditions such as water movement and nutrient availability on photosynthetic activity.

With the choice of an extremely sheltered site, the effects of water movement are minimal and even if it is difficult to provide an absolute assessment of available light energy within the action spectrum of the alga, any error should be consistent within photosynthetic and growth studies.

Saturation irradiance for the whole frond in these static conditions is about $24 \mathrm{Wm}^{-2}$, ie. slightly higher than the $17 \mathrm{Wm}^{-2}$ quoted for Laminaria byperborea by Lüning (1971), and represents photosynthetically active radiation (P. A. R.). However, saturation irradiance varies in different lamina regions, the meristem with its lower chlorophyll level (area basis) having a lower saturation irradiance of about $10 \mathrm{Wm}^{-2}$, whilst saturation in the $15-45 \mathrm{~cm}$ region of the frond is in excess of $25-30$ $\mathrm{Wm}^{-2}$. At saturation irradiance the photosynthetic rate of in situ static tissue ranges from $4 \mu \mathrm{g} \mathrm{Ccm}^{-2} \mathrm{~h}^{-1}$ in meristematic tissue to over $8 \mu \mathrm{g} \mathrm{Ccm}^{-2} \mathrm{~h}^{-1}$ in mature tissue. Laboratory studies of photosynthesis suggest much higher figures, over $20 \mu \mathrm{g} \mathrm{Ccm}^{-2} \mathrm{~h}^{-1}$, particularly in agitated water conditions.

There is considerable seasonal and tissue variation in respiratory activity, the highest frond figure being $0.15 \mathrm{mg} \mathrm{C} \mathrm{g}^{-1} \mathrm{dry} \mathrm{wt} \mathrm{h}^{-1}$, which is close to those quoted for L. byperborea by Lüning (1971).

\section{The kelp frond in winter}

In the winter months photosynthetic carbon fixation was at a minimum owing to the low light intensity and short day length. From November to January respiration exceeds photosynthesis in most of the frond regions. Disregarding possible reserve utilisation, a positive carbon balance may be achieved in these months by including dark fixation in the total carbon input since dark fixation accounts for over $40 \%$ of total carbon input in these months. It is also interesting to note that some of the figures recorded for dark fixation were the highest in the year eg. over $20 \mu \mathrm{g} \mathrm{Ccm}^{-2} \mathrm{day}^{-1}$ in the $15-45 \mathrm{~cm}$ frond region in November, where light fixation accounts for only $18.2 \mu \mathrm{g} \mathrm{Ccm}^{-2} \mathrm{day}^{-1}$.

A physiological problem which remains to be solved, is the nature of the energy and reducing power sources for dark fixation. Although mannitol would seem a likely candidate and does show a slight winter decrease such fluctuations do not always match the intensity of dark fixation, preliminary studies suggest the polyphenols as both a source of energy and reducing powers but this possibility awaits more detailed confirmation.

Amputation experiments by Lüning (1969) showed that for new frond growth in Laminaria byperborea kept in darkness the old frond was required. Luining suggested that this was due to mobilisation of reserve mannitol and laminarin in the old frond, followed by translocation to the newly formed tissue. It has been assumed that these carbohydrates act in a similar storage capacity in $L$. saccharina, a theory usually sub- 
stantiated by the decrease in laminarin and mannitol recorded in L. saccharina plants during these winter months (Black, 1950).

However, not only do the present production studies suggest such reserves are unnecessary but work in progress demonstrates that any laminarin remaining in winter plants is situated in distal tissue and the decrease recorded by Black (1950) was due to this tissue being discarded from the end of the frond. This phenomenon is further confirmed by the examination of plants from extremely sheltered sites, which often retain such laminarin-rich tissue until as late as May (Johnston et al., in press). These differences between $L$. saccharina and $L$. byperborea may reflect the somewhat different growth strategy of these species. It is possible, however that such distal laminarin could be mobilised under very poor winter conditions but no data to date confirms such reserve mobilisation in $L$. saccharina.

Earlier workers have suggested the need for a heterotrophic carbon supply for laminarian growth in winter months, as has been suggested by Wilce (1967) for Arctic algae. Although heterotrophy might be required in Arctic conditions in winter, but is as yet unconfirmed, such an explanation seems unnecessary in Scottish waters. Similarly, present claims for the need for heterotrophy in deep water brown seaweed populations need much more careful assessment. Studies in this laboratory indicate that L. saccharina plants grow to a depth in excess of $30 \mathrm{~m}$ and even at that depth produce excess storage carbon (laminarin) in summer months (Penny, personal communication).

\section{The carbon requirements of growth}

According to Parke (1948), new tissue growth in Laminaria saccharina is confined to the lowermost $10 \mathrm{~cm}$ of the frond. The L. saccharina plants at this Loch Creran site exhibit some slight frond elongation above this point and for the purpose of this investigation, linear growth was assumed to be restricted to the $0-15 \mathrm{~cm}$ zone of the frond. The carbon content of dry frond tissue was taken as $32.6 \%$ which was the mean of values obtained in an initial study (unpublished). This compares with the values of 29.3 and 32.7 reported by Mann (1972) for L. longicruris and L. digitata respectively. Mann also reported that the carbon content did not show significant seasonal variation.

During March the frond is in a period of very active growth, a time when mannitol and laminarin are both at a minimum. The net direct photosynthetic carbon input into the $0-15 \mathrm{~cm}$ growth region is $0.529 \mathrm{~g}$, yet the growth demand is $2.12 \mathrm{~g}$ C. Thus over $75 \%$ of the required carbon must be supplied from mature tissue, tissue which clearly has, even as early as March, a considerable assimilatory surplus. Radiotracer evidence confirms the translocation of such recent photosynthate from mature to meristematic tissue, as reported by other workers in both L. byperborea and L. saccharina (Schmitz et al., 1972; Lüning et al., 1973).

Analysis of the carbon input and demand for the meristematic region of the frond $(0-15 \mathrm{~cm})$ throughout the year indicates, in fact, that it usually has a carbon deficit, implying that basipedal translocation of carbon from the mature frond is required throughout most, if not all, the year. Because the new frond is dependent on the mature tissue for carbon suggests that there is a minimum frond length for carbon 
demand to be satisfied. This agrees with the findings of Lüning et al. (1973) which demonstrate translocation of recent $\left({ }^{14} \mathrm{C}\right)$ photosynthate throughout the year and a linear relationship was observed between frond elongation and initial frond length. In contrast, basipedal translocation in L. byperborea only occurs in the season of rapid growth and ceases in the summer and autumn. From amputation experiments, Lüning et al. (1973) concluded that the lowermost $10 \mathrm{~cm}$ of the frond of $L$. saccharina from Helgoland obtained $70 \%$ of the organic material necessary for growth by translocation, which is in very close agreement with this in situ study.

Although these studies indicate an ample supply of carbon for rapid tissue growth early in the year, the high demand for nitrogen would seem a major limiting factor particularly when in competition with the phytoplankton bloom. Certainly a nitrogen rather than a carbon reserve would seem essential to explain the carly aggressive growth strategy of $L$. saccharina as well as the continued growth in early summer after the phytoplankton bloom has apparently been limited by nutrient supply.

During the phase of rapid frond growth the linear relationship between frond length and rate of growth (Lüning et al., 1973) has been attributed to the carbon requirements for growth. Although the theoretical minimum size of a frond approaches the true size in winter and early spring months (100-120 cm) from late spring the proximal $45 \mathrm{~cm}$ of frond meets all growth-carbon demands yet a longer frond (over $100 \mathrm{~cm}$ ) appears necessary whilst rapid growth continues, perhaps to supply nitrogenous or other nutrient materials and growth factors rather than the quoted carbon. This would necessitate the translocatory system playing a key role by transporting nutrients.

\section{Carbon surplus}

Once the growth requirements for carbon can be met by the proximal frond region, a large assimilatory surplus is available in the remainder of the frond which in this nutrient limited site results in a rapid build up of storage carbon material, mainly mannitol and laminarin, resulting obviously in a vast increase in frond total carbon and dry weight. In both this study and that of Black (1950), involving plants from a similar sheltered sea-loch site, mannitol increases first (late March) followed by laminarin in April, mannitol level being much more sensitive to changes in photosynthesis. For example the drop in photosynthesis during the poor water conditions in May-June resulted in a drop in mannitol with no significant effect on the steady laminarin increase. Mannitol reached a peak level, perhaps physiological saturation, in July but laminarin increase continued into late summer.

A study of the seasonal changes in storage compounds must be undertaken against the concept of the frond as a continually growing belt of moving tissue. Tissue formed in March, with the metabolic characteristics of rapidly dividing and differentiating tissue will change in role in May to a region of high photosynthetic capacity, synthesising surplus carbon compounds. Thus tissue formed in early summer will gradually be pushed out towards the distal tip, synthesising more and more of these surplus carbon compounds.

What is the fate of this excess carbon input? Clearly much of it is stored as 
carbohydrate, either the polyol mannitol or the polysaccharide laminarin which reach highest concentrations in $\mathrm{d}$ i s $\mathrm{t}$ a 1 tissue in late summer.

However a close consideration of the carbon input - utilisation budget (Fig. 9) shows a major discrepancy. The apparent $\mathrm{C}$-demand (ie. the sum of growth-C, mannitol-C and laminarin-C) leaves a considerable excess of available carbon in late summer-autumn.

This difference between input and apparent utilisation could be accounted for in several ways, including (1) error in calculation of net-C input ie. over-estimate; (2) error in calculation of apparent demand; (3) the excess input is genuine but it is released as extracellular secretions.

A possible error (or at least incorrect assumption) in the estimation of net-C input could result from product inhibition of photosynthetic carbon input in tissue with very high laminarin levels. This effect might not be noted in short-term ${ }^{14} \mathrm{C}$-studies but might reduce $s$ u $\mathrm{t}$ a in ed high carbon input.

Certainly an error could occur in the estimation of apparent demand. The plantplant variation in storage carbon levels is extremely great, particularly in exact pattern along the frond, therefore making extrapolation from population data to a "typical frond" difficult. Also the extreme distal tissue is decaying and the percentage loss by leaking, which is clearly significant, varies considerably between plants.

Another source of significant under-estimation of storage-carbon levels is the assumption made in this preliminary budget that mannitol and laminarin represent all storage material. Extrapolation from Black's work on the chemistry of autumn plants suggests that about $15 \%$ of organic matter increase is not accounted for by laminarin and mannitol, and certainly studies being undertaken in this laboratory show that phluoroglucinol-based polyphenolics show considerable increase over the summer months, accounting for $1.5 \%$ of the dry weight in autumn plants.

However even with some allowance for the just mentioned factors (1) and particularly (2), there is an excess of carbon input not accountable in terms of growth or the accumulation of storage material - of the order of 25-35\% of gross photosynthesis - extracellular loss appearing the likely candidate. Although the subject of a separate paper (Jones \& Johnston, in press) the key findings regarding extracellular secretion from Laminaria are essential in the consideration of this preliminary budget.

\section{Extracellular secretions}

If the discrepancy between apparent carbon input and utilisation budgets is to be explained in terms of a considerable release, over $30 \%$ of the fixed carbon, of extracellular products this reopens an important controversy.

Studies in this laboratory indicate low secretion rates of ${ }^{14} \mathrm{C}$-extracellular products compared to unlabelled extracellular secretion. The maximum value for ${ }^{14} \mathrm{C}$ extracellular loss from Laminaria saccharina over 2 days was $0.67 \%$ of ${ }^{14} \mathrm{C}$-photosynthate. Similarly, Harlin \& Craigie (1975) demonstrated that between 0.6 and $1.4 \%$ of photoassimilated ${ }^{14} \mathrm{C}$ was secreted by Ascopbyllum nodosum during a 7 day period. These findings suggest a low entry rate of newly fixed carbon into the secretion process. 
However, in situ experiments with these L. saccharina plants in Loch Creran suggest that fairly high levels of carbohydrate and polyphenolic material (phluoroglucinol-based) are released in late summer, particularly from mature and distal tissue. Figures of over $36 \%$ of gross photosynthetically-carbon have been obtained, apparently showing a diurnally varying pattern of secretion, particularly of polyphenolic material. Such figures are similar to those reported by Khailov \& Burlakova (1969), Sieburth (1969) and Kroes (1970).

Although the major secretory period appears in late summer after excess carbon appears to have reached maximal levels in laminarin reserves, secretion is still noted in other seasons, particularly during the spring growth phase, but at relatively low rates. It thus seems, that both from direct investigation and extrapolation from carbon input/utilisation budgeting, a major proportion of laminarian productivity contributes to inshore dissolved organic matter (DOM), averaging over the year about $13 \%$ of gross photosynthetic carbon input, and up to $10 \%$ as leakage from distal tissue.

A current study of laminarians in Canadian waters, based on input/utilisation budgeting, suggests the apparent release of an even higher percentage of fixed carbon as extracellular products (Mann, personal communication), but their figure would include both true secretion and leakage.

\section{The effects of environmental regime on growth and budget of the frond}

The carbon balance/growth "model" described in this paper relates to a nutrient limited shelter water form of Laminaria saccharina. If applied to plants growing in an area of considerable water movement (particularly strong currents) present experimental findings would suggest: (1) increased rate of primary gross photosynthesis resulting from improved ion exchange at the frond surface (reduction of diffusion restraints); (2) improved supply of nutrients, leads to a greater flow of fixed carbon into growth than into storage routes; which in turn leads to - (3) generation of even more potential photosynthetic tissue, hence still greater primary carbon input. This explains the presence of "giant" plants (over $5 \mathrm{~m}$ ) in strong current areas and the low levels of storage materials (eg. laminarin) in such exposed site plants, found in this study and explains earlier findings (Parke, 1948; Black, 1950; Powell, 1972).

\section{Contribution to the ecosystem}

Short-term experiments appear to measure total carbon input before any losses due to tissue erosion or extracellular secretion, and indicate a net annual primary production of $120 \mathrm{~g} \mathrm{C} \mathrm{m}^{-2}$ frond giving, with the leaf area index quoted as approximately unity, a net annual community production of $120 \mathrm{~g} \mathrm{C} \mathrm{m}^{-2}$ year $^{-1}$ for the laminarian zone.

The suggested fate of carbon assimilated by a laminarian frond is summarised in Figure 10. After the respiratory loss of approximately $38 \%$ of gross carbon fixation 
the remaining carbon is released as detritus from the distal region of the frond (minimum of $40 \%$ ), as soluble materials by active secretion (approx. $13 \%$ ) or leakage from distal tissue $(10 \%)$, much of these latter solubles providing valuable carbon sources for associated microbial populations (Laycock, 1974) and thence entry to particulatefeeding food chains.

A comparison of $L$. saccharina productivity with phytoplankton productivity in Loch Creran shows some interesting features. Tett et al. (1975) estimate net phytoplankton productivity in Loch Creran to be between $40-100 \mathrm{~g} \mathrm{C} \mathrm{m}^{-2}$ year $^{-1}$ in the euphotic zone. The productivity of $120 \mathrm{~g} \mathrm{C} \mathrm{m}^{-2}$ year $^{-1}$ for L. saccharina is certainly comparable with the highest values for phytoplankton. Approximately $25 \%$ of the area of Loch Creran is within the laminarian zone depth limit contour of $8-10 \mathrm{~m}$, which suggests that $L$. saccharina primary production contributes approximately $25 \%$ of total primary production in the Loch, ie. by extrapolation about 360 metric tons carbon for a loch with a $0-10 \mathrm{~m}$ zone of about $3.0 \times 10^{6} \mathrm{~m}^{-2}$ (Fig. 1). If the littoral seaweeds, which form a rich flora, were included in such comparisons, the contribution for the loch would be considerably higher.

Clearly, it appears that the macroalgae contribute a major proportion of the primary production of inshore waters and form the basis of many detritus and filterfeeding food chains. It, thus, seems likely that some of the presently developed "models" for inshore energetics may require some considerable modification in view of these and other (Mann, 1972) recent studies of seaweed productivity.

Acknowledgements. This work was carried out whilst the senior author (Johnston) held research grants from the Natural Environment Research Council (GR3/1182A and 1807A) and research studentships from the NERC were held by both Jones and Hunt. The authors wish to acknowledge the considerable assistance given by the Director and staff of the Scottish Marine Biological Association, the work being carried out in close collaboration with the programme of $\mathrm{H}$. T. Powell.

\section{LITERATURE CITED}

Black, W. A. P., 1950. The seasonal variation in weight and chemical composition of the common British Laminariaceae. J. mar. biol. Ass. U.K. 29, 45-72.

Blinks, L. R., 1955. Photosynthesis and productivity of littoral marine algae. J. mar. Res. 14, 363-373.

Brylinsky, M., 1971. Release of dissolved organic matter by marine macrophytes. Ph. D. thesis, Univ. of Georgia, 180 pp.

Harlin, M. M. \& Craigie, J. S., 1975. The distribution of photosynthate in Ascopbyllum nodosum as it relates to epiphytic Polysiphonia lanosa. J. Phycol. 11, 109-113.

Johnston, C. S., 1969. The ecological distribution and primary production of macrophytic marine algae in the Eastern Canaries. Int. Revue ges. Hydrobiol. 54, 473-490.

- \& Cook, J. P., 1968. A preliminary assessment of the techniques for measuring primary production in macrophytic marine algae. Experientia 24, 1176-1177.

- Ferrier, N. C. \& Jones, R. G., 1977. A critical assessment of estimates of macroalgal primary production based on short-term measurements of photosynthesis. In: Proceedings of the international Seaweed Symp. 8 (in press).

Kanwisher, J. W., 1959. Polarographic oxygen electrode. Limnol. Oceanogr. 4, 210-217.

- 1966. Photosynthesis and respiration in some seaweeds. In: Some contemporary studies in marine science. Ed. by H. Barnes. Allen \& Unwin, London, 407-420. 
Khailov, K. M. \& Burlakova, Z. P., 1969. Release of dissolved organic matter by marine seaweeds and distribution of their total organic production to inshore communities. Limnol. Oceanogr. 14, 521-527.

Kroes, H. W., 1970. Excretion of mucilage and yellow-brown substances by some brown algae from the intertidal zone. Botanica mar. 13, 107-110.

Laycock, R. A., 1974. Detrital food chain based on seaweeds. 1. Bacteria associated with surface of Laminaria fronds. Mar. Biol. 25, 223-232.

Lewis, D. H. \& Smith, D. C., 1967. Sugar alcohols (polyols) in fungi and green plants. 2. Methods of detection and quantitative estimation in plant extracts. New Phytol. 66, $185-204$.

Lüning, K., 1969. Growth of amputated and dark exposed individuals of the brown alga Laminaria hyperborea. Mar. Biol. 2, 218-223.

- 1971. Seasonal growth of Laminaria byperborea under recorded underwater light conditions near Helgoland. In: Proceedings of the 4th European Symposium on Marine Biology. Ed. by D. J. Crisp. Cambridge Univ. Press, Cambridge, 347-361.

- Schmitz, K. \& Willenbrink, J., 1973. $\mathrm{CO}_{2}$-fixation and translocation in benthic marine algae. III. Rates and ecological significance of translocation in Laminaria byperborea and L. saccharina. Mar. Biol. 23, 275-281.

Mann, K. H., 1972. Ecological energetics of the sea-weed zone in a marine bay on the Atlantic coast of Canada. II. Productivity of the seaweeds. Mar. Biol. 14, 199-209.

Moebus, K. \& Johnson, K. M., 1974. Exudation of dissolved organic carbon by brown algae. Mar. Biol. 26, 117-125.

Parke, M., 1948. Studies on British Laminaraceae. I. Growth in Laminaria saccharina (L.) Lamour. J. mar. biol. Ass. U.K. 27, 651-709.

Powell, H. T., 1972. The ecology of the macroalgae in sea lochs in Western Scotland. In: Proceedings of the International Seaweed Symposium. Ed. by K. Nisizawa. Univ. Tokyo Press, Tokyo, 1, 273 pp.

Schmitz, K., Lüning, K. \& Willenbrink, J., 1972. $\mathrm{CO}_{2}$-fixation and translocation in benthic marine algae: II. On translocation of ${ }^{14} \mathrm{C}$-labelled assimilates in Laminaria byperborea and L. saccharina. Z. PflPhysiol. 67, 418-429.

Sieburth, J. M., 1969. Studies on algal substances in the sea. III. The production of extracellular organic matter by littoral marine algae. J. exp. mar. Biol. Ecol. 3, 290-309.

Steeman-Nielsen, E., 1952. The use of radio-active carbon (C 14) for measuring organic production in the sea. J. Cons. perm. int. Explor. Mer 18,117-140.

Strickland, J. D. H. \& Parsons, T. W., 1968. A practical handbook of seawater analysis. Bull. Fish. Res. Bd Can. 167, 311 pp.

Tett, P. B., Wallis, A., Wood, B. J. B. \& Jones, K., 1975. Organic production in sea-lochs, with particular reference to the phytoplankton in Loch Creran. 7th. scient. Meet. Scott. Mar. Biol. Ass. 4 pp (mimeo).

Watson, G. R. \& Williams, J. P., 1970. Rapid method for wet combustion and scintillation counting of ${ }^{14} \mathrm{C}$ labelled organic materials. Analyt. Biochem. 33, 356-365.

Wilce, R. T., 1966. Heterotrophy in Arctic Sublittoral Seaweeds: An Hypothesis. Botanica mar. 10, 185-197.

Wilson, G., 1972. Studies on some plant and bacterial carbohydrases. Ph. D. thesis, HeriotWatt Univ., Edinburgh, 159 pp.

First author's address: C. S. Johnston

Department of Biological Sciences

Heriot-Watt University

Chambers Street

Edinburgh, Scotland

U.K. 